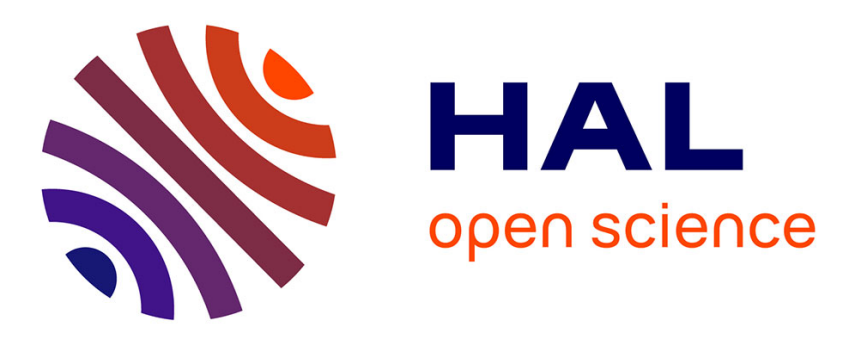

\title{
Microwave dielectric spectroscopy for biological cells suspensions analysis and proliferation evaluation
}

François Artis, David Dubuc, Jean-Jacques Fournié, Mary Poupot, Katia

Grenier

\section{- To cite this version:}

François Artis, David Dubuc, Jean-Jacques Fournié, Mary Poupot, Katia Grenier. Microwave dielectric spectroscopy for biological cells suspensions analysis and proliferation evaluation. 44th IEEE European Microwave Conference, Oct 2014, Rome, Italy. pp.275-278, 10.1109/EuMC.2014.6986423 . hal-01951708

\author{
HAL Id: hal-01951708 \\ https://hal.laas.fr/hal-01951708
}

Submitted on 9 Dec 2019

HAL is a multi-disciplinary open access archive for the deposit and dissemination of scientific research documents, whether they are published or not. The documents may come from teaching and research institutions in France or abroad, or from public or private research centers.
L'archive ouverte pluridisciplinaire HAL, est destinée au dépôt et à la diffusion de documents scientifiques de niveau recherche, publiés ou non, émanant des établissements d'enseignement et de recherche français ou étrangers, des laboratoires publics ou privés. 


\title{
Microwave dielectric spectroscopy for biological cells suspensions analysis and proliferation evaluation
}

\author{
François Artis ${ }^{1,2,3}$, David Dubuc ${ }^{1,2}$, Jean-Jacques Fournié ${ }^{3}$, Mary Poupot $^{3}$, and Katia Grenier ${ }^{1,2}$ \\ ${ }^{1}$ CNRS, LAAS, 7 avenue du colonel Roche, F-31400 Toulouse, France \\ ${ }^{2}$ Univ de Toulouse, UPS, LAAS, F-31400, Toulouse, France \\ ${ }^{3} \mathrm{CRCT}$, Toulouse, France
}

\begin{abstract}
This paper presents the capabilities of microwave dielectric spectroscopy for biological cells suspensions analysis. The developed biosensor integrates both microfluidic channel for biological samples manipulation together with a microwave circuit for dielectric spectroscopy. Experimental investigation validates the success and accuracy of the microwave dielectric spectroscopy technique. This technique is applied with various cells concentrations in suspension in their culture medium. Results demonstrate that both real and imaginary parts of the contrast of the dielectric permittivity are proportional to the cells concentration with a correlation coefficient (R-square) greater than 0.99. The technique is consequently suitable for proliferation evaluation of cells. More widely, this work contributes to settle down the capabilities of microwave sensing for biochemical and bio-cellular analysis applications.
\end{abstract}

Keywords-Chemical and biological sensor, microwave, microfluidic

\section{INTRODUCTION}

Traditional biochemical and bio-cellular analytic tools, like flow cytometry for instance, already provide quantitative and qualitative information of cells very efficiently. However these techniques are time consuming, as it requires the preparation of the samples with labels. Investigated cells are also submitted to a laser illumination, which may drastically damage the biological samples.

Consequently, new biosensing tools, permitting to operate (1) non-invasively, i.e. without interfering and altering the cells, (2) in a biological medium environment and (3) at a microscale to fit with cells' dimensions, may provide real added value in complement with classical cellular analyzing tools.

Due to the possible convergence of microfluidics [1-3] with microwave circuits, it is now possible to consider microwave-based biosensing at the cellular level as a good candidate for lab-on-chip applications. This emerging detection and analyzing technique has indeed already demonstrated attractive features fitting the three aforementioned challenges [4-8]. Microwave sensing may thus provide an innovative way to investigate biological cells for medical applications. Combined with the miniaturization and parallelization capabilities offered by the micro and nanotechnologies [6-8], really innovative microwave microsensors are now to be considered as excellent challenger for biosensing.

In this context, this publication aims consequently to demonstrate the capabilities of microwave dielectric spectroscopy for biological cells suspensions analysis. The two next paragraphs detail the biosensor architecture, microfabrication and experimental setup and protocols. Experimental results are presented in part IV. Accuracy of the dielectric spectroscopy is demonstrated for cells concentrations ranging from 4 to 35 millions of cells per milliliter of culture medium. This result consequently points the capabilities of microwave dielectric micro-spectroscopy for non-invasive cells proliferation quantification.

\section{Microwave Dielectric Spectroscopy: DeVICE ARCHITECTURE AND MICROFABRICATION}

To perform microwave dielectric spectroscopy on biological cells solutions, a coplanar waveguide is used with a microfluidic channel perpendicularly placed on top, as presented on the schematic of Figure 1. This channel permits to precisely localize the biological samples.

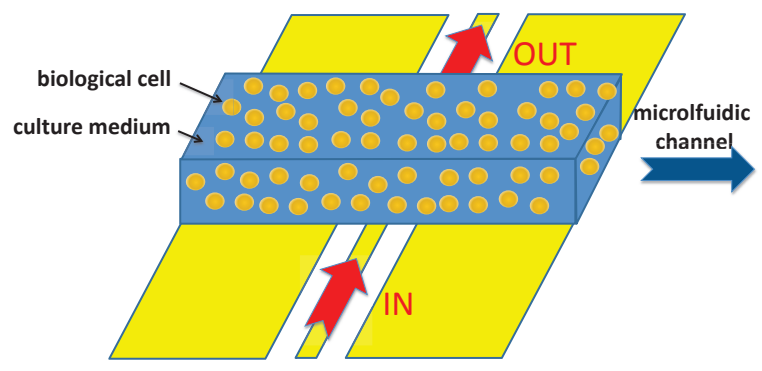

Fig. 1. Device's architecture for broadband dielectric spectroscopy of liquid

The technological process to elaborate such a component is simple. A gold metallization is patterned on a quartz substrate, whereas a PDMS elastomer is used to realize the microfluidic channel. Both are assembled thanks to a plasma-bonding process. More details may be found in [8].

To better illustrate the developed structure, Fig. 2 presents a microphotograph of the microfluidic coplanar waveguide 
loaded with a cells suspension. The cells are in liquid, in their traditional culture medium, and may be distinguished on the gold waveguide as the numerous bright dots.

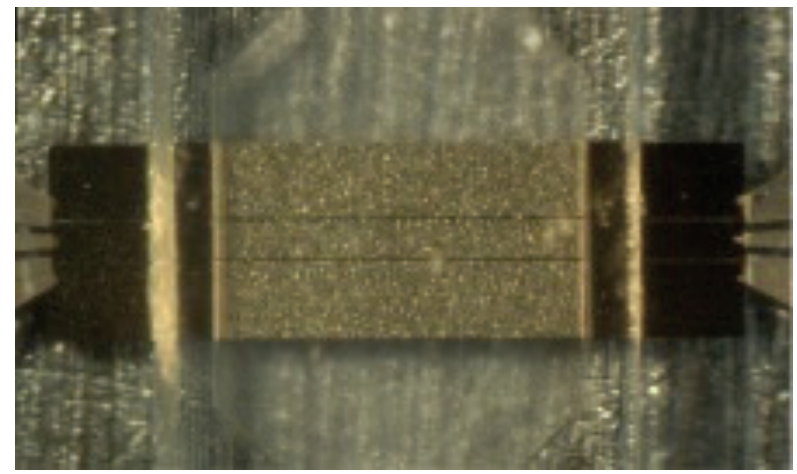

Fig. 2. Microphotograph of the microfabricated device dedicated to the microwave dielectric spectroscopy of biological cells suspensions, loaded with a cells suspension

Next paragraph introduces the microwave and biological protocol developed to accurately characterize the biological samples through dielectric permittivity extraction.

\section{MicrowaVE AND Biological Protocol}

As far as both microfluidic capabilities and microwave measurements are jointly considered, a specific test setup is developed. Measurements of the microwave biosensor are performed on wafer with a probe station and two coplanar probes connected to an ANRITSU 37369C vector network analyzer. A thermal system is used to assure a stable liquid temperature of $20^{\circ} \mathrm{C} \pm 0.1^{\circ} \mathrm{C}$. The probe system is also equipped with a microscope allowing the visual inspection of the correct liquid filling inside the channel.

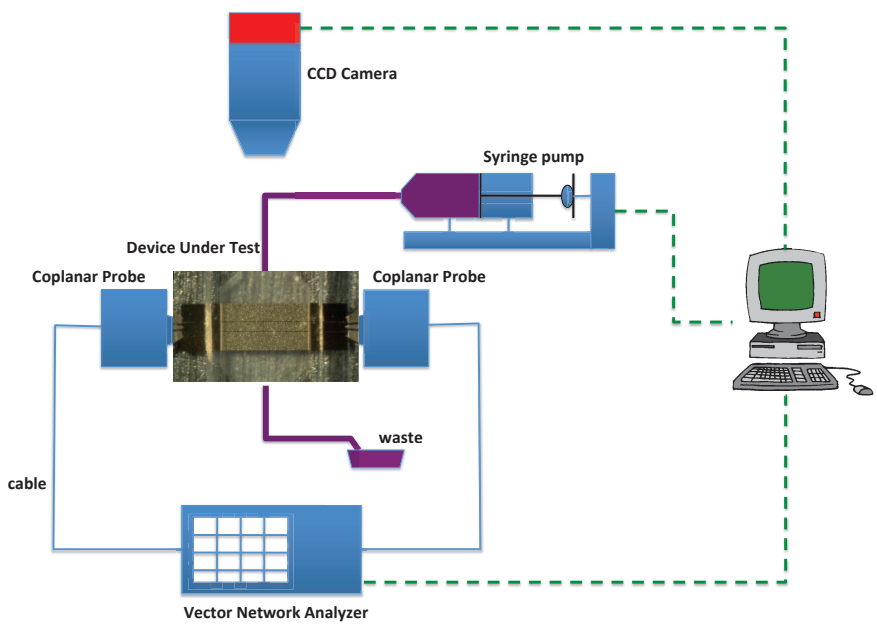

Fig. 3. Microwave and microfluidic test setup

Prior to biological measurements, a full-two-port SOLT calibration procedure is applied using CSR 8 calibration standards. The frequency range extends from $40 \mathrm{MHz}$ to 40 GHz. Values of the liquids' complex permittivity are determined by means of a broadband measurement technique $[6,8]$. The test setup also includes microfluidic inlet and outlet of bio-species under investigation, which injection is driven by a syringe pump. Finally, a PC and appropriate software assure the controls and measurements of the test setup. The architecture of the test setup is presented in the Fig. 3.

As far as biological samples are concerned, B lymphomas cells of RL type, which are traditionally employed as a reference model by biologists for blood cancer investigations, are used in this study. To prepare the cells for the HF measurements and assure that they are healthy during characterization, a biological protocol is appropriately developed for living cells analysis. After their culture in an incubator, the cells are collected and placed in an Eppendorf tube within their culture medium (reference medium), as indicated in Fig. 4.

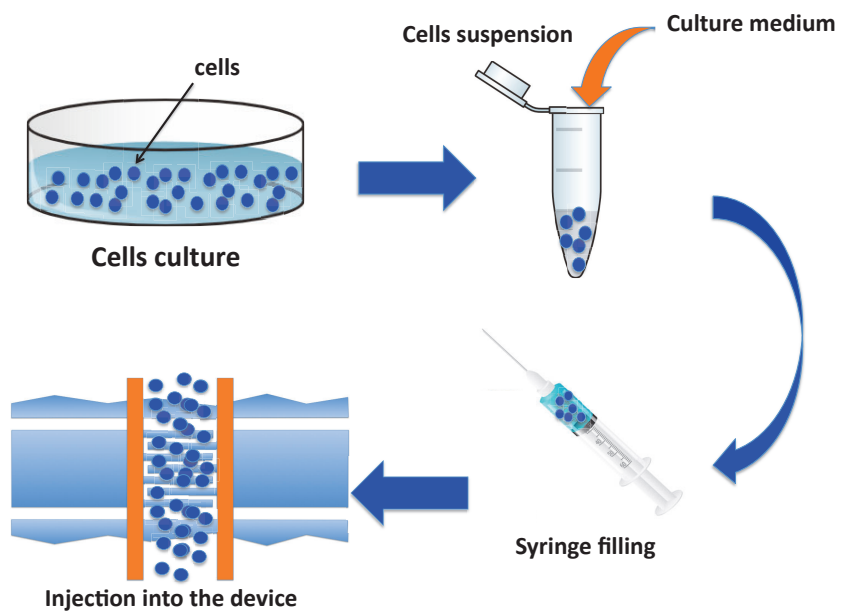

Fig. 4. Biological protocol for cells preparation before microwave measurements

The used culture medium corresponds to the Roswell Park Memorial Institute one, called RPMI, with $10 \%$ of Fetal Bovin Serum (FBS). For this work, 4 cells concentrations are prepared: 4, 8, 17 and 35 millions cells per milliliter plus a pure reference medium (which corresponds to a null conc. of cells).

\section{RESULTS AND DISCUSSION}

The microwave dielectric spectroscopy has been performed when the microfluidic channel is successively filled with the five bio-liquids. The first tested liquid corresponds to pure RPMI medium, which serves to normalize the complex permittivity of each following measurements according to :

$$
\Delta \varepsilon_{X}=\varepsilon_{X}-\varepsilon_{R P M I}
$$

where $\varepsilon_{X}$ and $\varepsilon_{\text {RPMI }}$ correspond to the extracted complex permittivity when cells suspension and RPMI medium (resp.) are filled in the channel. $\Delta \varepsilon_{X}$ consequently corresponds to the 
permittivity contrast of cells suspension relative to their host medium.

\section{A. Experimental results from microwave dielectric spectroscopy}

Figures 5 and 6 present the real and imaginary (resp.) parts of the permittivity contrast. As RPMI serves as reference, its associated permittivity (both real and imaginary parts) corresponds to a null contrast.

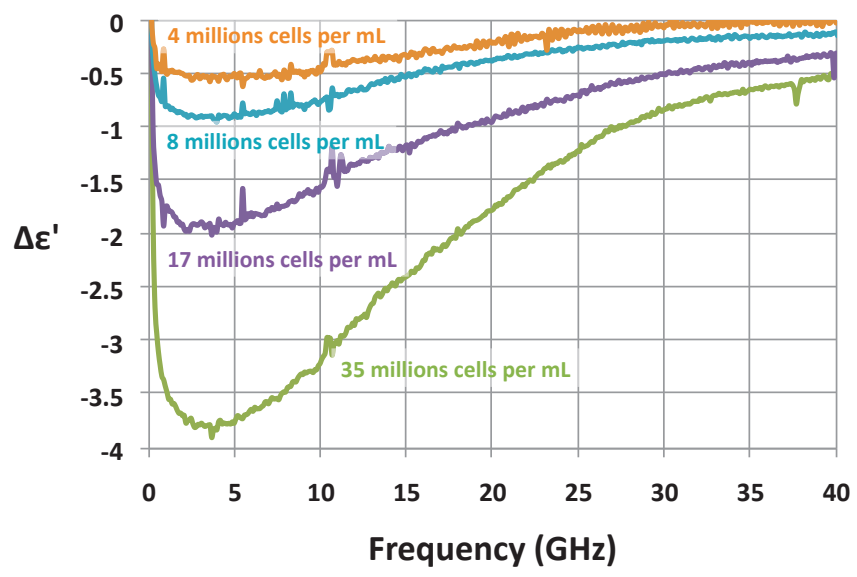

Fig. 5. Microwave dielectric spectroscopy (real part) of biological cells suspension with increasing cells concentration

As it can be seen on these two figures, the dielectric signatures are clearly distinguishable even for low cells concentrations. This is made possible as permittivity contrasts are extracted instead of direct values of permittivity, as in [9]. We would like also to rise that a cell concentration of 4 millions cells per milliliter represents a low cells concentration value, which is classically used during bio-experiments.

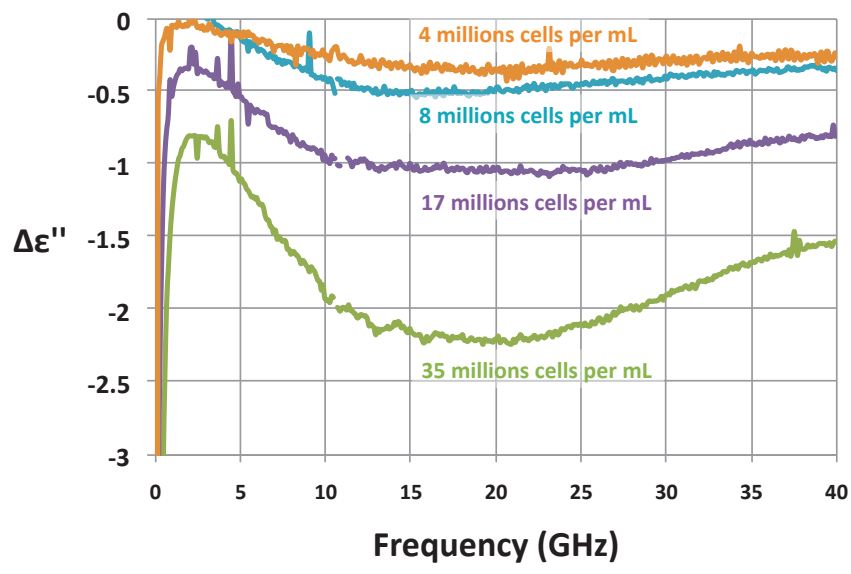

Fig. 6. Microwave dielectric spectroscopy (imaginary part) of biological cells suspension with increasing cells concentration

This demonstrates that microwave dielectric spectroscopy reaches sufficient accuracy for biological cells suspension quantification/analysis.

\section{B. Application of microwave dielectric spectroscopy for cells proliferation evaluation}

This part exploits the last remark. The cells suspension quantification is indeed of importance for efficient medication discovery. For such an application, targeted cells are submitted to medication in charge of inducing cell apoptosis (programmed death). This final cell state is evaluated when cells stop to proliferate. It is consequently mandatory to develop high throughput screening (HTS) of cell proliferation quantification systems.

Our development aims to demonstrate that microwave dielectric spectroscopy is a good candidate for such an application. Moreover, the integrability of the microwave technique, on the contrary to optical or laser-based techniques, makes possible to have access to a lab-on-chip HTS, which is mandatory to develop personalized medicine.

Table I regroups the dielectric values at $10 \mathrm{GHz}$ obtained for the various cells concentrations. This table also recalls the standard deviation obtained from repetitive tests [10].

TABLE I. DIELECTRIC VALUES AT $10 \mathrm{GHZ}$

\begin{tabular}{|c|c|c|c|c|}
\hline \multirow{2}{*}{$\begin{array}{c}\text { Biological } \\
\text { cells } \\
\text { concentration } \\
\text { in millions } \\
\text { cells per } \mathrm{ml}\end{array}$} & \multicolumn{2}{|c|}{$\begin{array}{c}\text { Dielectric contrasts at } \\
10 \mathrm{GHz}\end{array}$} & \multicolumn{2}{c|}{$\begin{array}{c}\text { standard deviation of } \\
\text { the dielectric values at } \\
\text { 10GHz [10] }\end{array}$} \\
\cline { 2 - 5 } & real part & $\begin{array}{c}\text { imaginary } \\
\text { part }\end{array}$ & real part & $\begin{array}{c}\text { imaginary } \\
\text { part }\end{array}$ \\
\hline 4 & -0.46 & -0.25 & - & - \\
\hline 8 & -0.75 & -0.41 & - & - \\
\hline 17 & -1.56 & -0.98 & 0.08 & 0.08 \\
\hline 35 & -3.17 & -1.93 & 0.05 & 0.03 \\
\hline
\end{tabular}

As can be noticed on Table I, the dielectric contrasts are larger than the typical standard deviation and the resolution can be estimated around 1 million cells per milliliter.

Figure 6 presents the dielectric contrast versus the cells suspension concentrations. The linear relationship between these two variables is assured with a correlation coefficient (Rsquare) larger than 0.99; which demonstrates the high level of accuracy of microwave dielectric measurements.

The linear regression performed on both the real and imaginary parts of the dielectric contrasts leads to define two sensitivities: -0.091 per million cells for the real part of the contrast and -0.055 per million cells for the imaginary part of the contrast. These two coefficients then permit to predict from any future microwave measurements the cells concentrations. One can notice that the sensitivity coefficients are cells, medium, device and selected frequency (here $10 \mathrm{GHz}$ ) dependents.

These results then demonstrate the ability of such a technique for cells quantification with a resolution around 1 million cells per milliliter. 


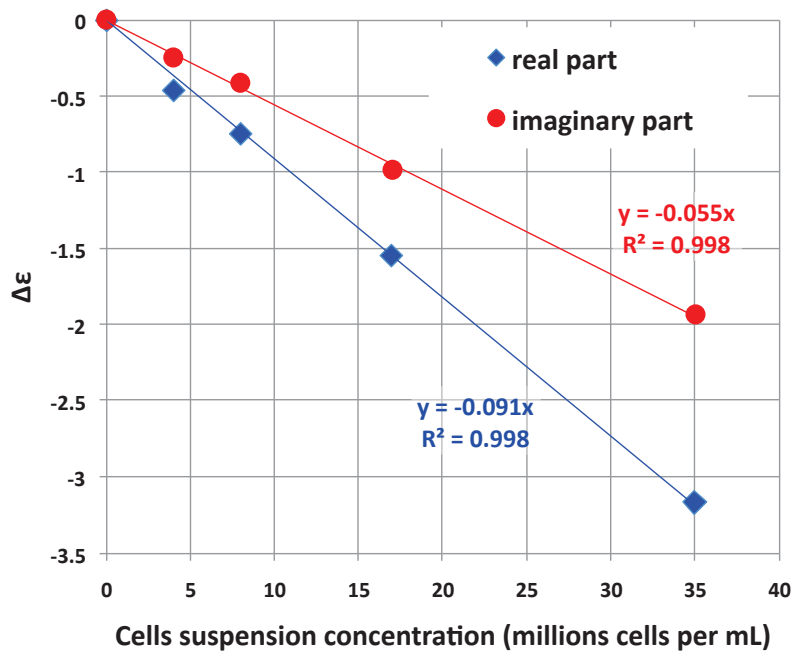

Fig. 7. Microwave dielectric parameters at $10 \mathrm{GHz}$ of biological cells suspension versus cells concentration

\section{CONCLUSION}

Capabilities of microwave dielectric spectroscopy technique are then experimentally demonstrated in the context of biological cell analysis/quantification. The technique has been evaluated with cells concentration as low as 4 millions cells per milliliter and resolution has been estimated around 1 millions cells per milliliter. Experimental results demonstrate that microwave dielectric parameters provide accurate readouts for cells proliferation quantification. Abilities of the developed technique in terms of cells suspension quantification, noninvasivity, operation in culture medium and high integrability, make the microwave dielectric spectroscopy a good candidate for high throughput screening applications.

\section{ACKNOWLEDGMENT}

The authors want to acknowledge the RITC foundation for its financial support as well as the RENATCH network for supporting the microfabrication of the device in the LAASCNRS clean room.

\section{REFERENCES}

[1] G.M. Whitesides, "The origins and the future of microfluidics," Nature, vol. 442, pp. 368-373, 2006.

[2] D. Di Carlo, L.P. Lee, « Dynamic single-cell analysis for quantitative biology », Analytical Chemistry, Dec. 2006, pp. 7918-7925

[3] J. El-Ali, P.K. Sorger, K.F. Jensen, "Cells on Chip", Nature 442, 403-411, 2006

[4] M. Hofmann, G. Fischer, R. Weigel, D. Kissinger, "Microwave-Based Noninvasive Concentration Measurements for Biomedical Applications", IEEETrans. on MTT vol.61, no.5, pp.2195,2204, May 2013

[5] Arne Jacob, EuMC2012 N. Haase, and A. F. Jacob, "Characterization of biological substances using a substrate integrated microwave near-field sensor", in Proc. European Microwave Conf., Oct. 2012, pp. 432435.

[6] J.C. Booth et al., "Quantitative permittivity measurements of nanoliter liquid in microfluidic channels to $40 \mathrm{GHz}$," IEEE T. on Instr. and Meas., vol. 59, n²12, 2010, pp. 3279-3288.

[7] Y. Yang, H. Zhang, J. Zhu, G. Wang, T.-R. Tzeng, X. Xuan, K. Huang, P. Wang, "Distinguishing the viability of a single yeast cell with an ultra-sensitive radio frequency sensor," Lab on a Chip, Vol. 10, pp. 553-555, 2010.

[8] K. Grenier, D. Dubuc, P. E. Poleni, M. Kumemura, H. Toshiyoshi, T. Fujii and H. Fujita, "Integrated broadband microwave and microfluidic sensor dedicated to bioengineering", IEEE Transactions on Microwave Theory an Techniques, vol. 57, no. 12, pp. 3246-3253, December 2009.

[9] D. Dubuc, K. Grenier, M. Poupot, J-J. Fournié, "Microwave signatures of Alive B-lymphoma cells suspensions," IEEE Radio and Wireless Symposium 2011 - Biowireless'11, Phoenix, USA, Jan. 2011.

[10]F. Artis, D. Dubuc, J.J. Fournie, M. Poupot, K. Grenier, "Microwave dielectric bio-sensing for precise and repetitive living cells suspension analysis," Microwave Conference (EuMC), 2013 European , vol., no., pp.468,470, 6-10 Oct. 2013 